in the country in which it occurs, even though it cannot be properly packed into European compartments.

My statement that "too much attention has been paid in the past to the palæontological evidence" is, when removed from its surroundings, obviously absurd. The point I wished to emphasise is merely that correlation based upon homotaxis can be pushed too far, and that it is unscientific to break up a uniform series of rocks that occurs in New Zealand into sharply separated divisions on the basis of the occurrence of fossils that in Europe are found at different horizons. It is in this sense only that I suggest that too much emphasis has been laid on the palæontological evidence in the past in New Zealand, especially as all the collections of fossils are still far from complete. I may add that for twenty years, owing to the influence of my old and revered teacher, the late Capt. Hutton, F.R.S., I endeavoured to apply his divisions of the vounger rocks of New Zealand to the districts where I was at work. As difficulties finally became insuperable, I visited his typical localities in the expec. tation of getting information that would solve them. It was to my intense disappointment that I was forced to the conclusion that his divisions of the "system" were based upon what I considered to be incorrect observation of the field evidence.

P. Marshall.

Otago University, Dunedin, New Zealand.

Prof. Marshall's clear statement of the palæontological difficulties in this case should stimulate the search for further fossiliferous horizons. The Ordovician and Gotlandian beds of the British Isles were laid down in many places "during the continuance of uniform physical conditions and in direct continuous succession" ; none the less, two systems have been conveniently maintained. The unwieldy "Karroo system" of South Africa would no doubt be split up were marine representatives of its strata available close at hand.

G. A. J. C

Dana's Proof of Darwin's Theory of Coral Reefs.

I THINK Mr. Pissland, in his letter to NATuRE of April 3 , is 3 wen in assigning a fault origin to the narrow "khors" which form the harbours along the Rea Sea coast. I visited a number of these during a land journey from Halaib to Port Sudan in Igo8, and although I had not much time for detailed investigation, I saw nothing which pointed to any other origin than erosion and subsidence. The steepsided character of the shallow valleys, which Mr. Crossland takes as indicative of a fault origin, is, I think, merely a consequence of the toughness of the coral-rock and the smallness of the rainfall in these regions. It is a character common to many inland "wadis" where there is no suspicion of rift action.

The occurrence of coral-reef coverings on the coasthills is, of course, a proof of elevation of the land; but on what does $\mathrm{Mr}$. Crossland base his conclusion that the elevation has been continuous? Has any systematic slickensiding or brecciation of the rocks, such as usually accompanies a fault, been observed along the sides of the valleys? Or has it been proved that the floors of the valleys consist of the same beds as occur at higher levels on either side?

Like Mr. Crossland, I write from the wilderness, and cannot now refer to the papers which he cites. But as an admirer of the devotion and skill with which Mr. Crossland has pursued his important biological researches on that desolate shore, I read his two last papers very carefully at the time of their NO. 2273 , VOL. 9I] publication. If my memory is correct, the papers contain no real evidence as to a fault-origin for the "khors." Rather does Mr. Crossland seem to take faulting for granted, and then to adopt it as the explanation for all the topographical features of the coast, even going so far as to regard Ras Raweiya as a piece torn from the mainland and shifted several miles out to sea-a view in which I imagine few geologists will agree.

Unless further facts can be adduced, I think the "khors" of the Red Sea coast are most reasonably explained as valleys which were eroded by streams when the land was at a greater elevation than it is now, and have since been submerged by subsidence.

Wadi Baba, Sinai, April 20.

\section{Sub-Red Crag Flint Implements and the Ipswich Skeleton.}

I Notice that Nature of May 8 contains an account of a paper read by Mr. W. H. Sutcliffe before the Manchester Literary and Philosophical Society, in which he refers to the sub-Red Crag flint implements and the pre-Chalky Boulder Clay human skeleton I have discovered.

Mr. Sutcliffe argues that because the rostro-carinate flints are found below the Red Crag, and (as he asserts) in the Palæolithic gravel of Hackney Downs, they cannot be of human origin, because it is "inconceivable that a human production should have retained exactly the same form throughout this immense period."

Apart from the fact that the rostro-carinate specimens have not retained exactly the same form during the periods in which they were used, it appears to have escaped Mr. Sutcliffe's notice that a river-gravel is composed of material of the most varied ages, and that therefore the examples of this type found in the Hackney Downs deposit need not necessarily be of Palæolithic age.

But even if they do belong to this period that has no bearing upon their "humanity"-the ordinary round-ended scraper was made in the most remote times, and is still used by the present-day Eslkimo. Mr. Sutcliffe has also apparently "found" that the rostro-carinate flints are "not adapted to any likely use," and cannot therefore be held to afford good evidence of Pliocene man.

This is a very shaky and unsound objection, as it is open to anyone to "find" that the ordinary Palæolithic implement is practically useless, and therefore nonhuman.

Mr. Sutcliffe has evidently not carefully read the published accounts of the evidence in favour of the high antiquity of the Ipswich man. It has never been sugorested that the skeleton was lying on a land surface of loose sand, and exposed to the direct action of moving ice, but that the bones had probably either been buried in that surface or covered by blown sand to a considerable depth.

If Mr. Sutcliffe had examined the evidence I have mentioned with an open and unbiassed mind, he would have recognised that the actual provenance of the Ipswich bones is as well established as any prehistoric skeleton yet unearthed.

J. REID MoIr.

\section{Openings Required for Laboratory Assistants.}

You have in the past been kind enough to insert a letter of mine with regard to the London County Council laboratory monitors, whose services the council is unable to retain after the age of seventeen, and whom it has requested this association to place in 